\title{
A BESZÉDFELDOLGOZÁS ÉS A JEGYZETELÉSI ELJÁRÁSOK ELMÉLETI ÖSSZEFÜGGÉSEI
}

\section{Szerző:}

Schéder Veronika

Debreceni Egyetem

Szerző e-mail címe:

veronika.scheder@gmail.com

\section{Lektorok:}

Tukacsné Károlyi Margit

Nyíregyházi Egyetem

Szabó Ferenc

Nyíregyházi Egyetem

Mező Katalin

Debreceni Egyetem

Nemes Magdolna

Debreceni Egyetem

Schréder V. (2016): A beszédfeldolgozás és a jegyzetelés mechanizmusainak elméleti összefüggései. Különleges Bánásmód, II. évf., 2016/1. szám, 7-15. DOI 10.18458/KB. 2016.1.7

\begin{abstract}
Absztrakt
Jelen írás azt igyekszik felfedni, hogy milyen összetett mechanizmusok mentén dolgozik az emberi agy, miközben az elhangzó beszédeket (iskolai vagy munkahelyi elöadások, különbözö tárgyalások stb. szövegét) az elhangzással egy idöben különféle jegyzetelési technikákkal próbálja láthatóvá és maradandóvá tenni. E tanulmány a beszéd feldolgozásának hierarchikus folyamatát mutatja be (a hallástól az értelmezésig), illetve azokat a paramétereket, amelyek az említett müködéseket befolyásolhatják, nehezíthetik, megzavarhatják.
\end{abstract}

Kulcsszavak: beszédfeldolgozás, beszédfeldolgozási zavarok, jegyzetelési nehézségek, memória

Diszciplínák: pszichológia, nyelvtudomány

\section{Abstract \\ THEORETICAL RELATIONS BETWEEN \\ SPEECH PROCESSING AND NOTE-TAKING PROCEDURES}

This paper makes an effort to reveal the complex mechanisms by which the human brain operates, when a person - by using various note-taking techniques - intends to create visible and lasting notes on spoken words, simultaneously with the speech (the contents of school or work presentations, or various discussions, etc.). This study describes the hierarchical procedure of speech processing (from hearing to perception), and also the parameters that may affect, impede, or perturb these operations.

Keywords: speech processing, speech processing disorders, note-taking difficulties, memory

Disciplines: psychology, linguistics 
A XXI. század elején tapasztalt széles körü és jelentős mértékü társadalmi változások az élet számos területén a fejlődés tendenciáinak elindítói voltak, másutt azonban, pl. az anyanyelvhasználat szempontjából kevésbé látszanak kedvezőeknek. Újabb kutatások bizonyítják, hogy az anyanyelvi készségek és a ráépülö tanulási folyamatok egyre több zavart szenvednek, és a problémák jelentős részét a beszédfeldolgozás nehézségei adják (lásd például: Gerliczkiné Schéder, 2007; Imre, 2007).

A beszédfeldolgozási zavarok feltételezett oki hátterét a legtöbben abban látják, hogy a multimédiás eszközök térnyerésével egyidejüleg interperszonális kapcsolataink háttérbe szorultak, kommunikációs szokásaink megváltoztak. Nemcsak kevesebb figyelem fordítódik az anyanyelvi készségek zökkenőmentes elsajátítására és használatára, hanem egyéb kedvezőtlen körülmények is megnehezítik azt. Ilyen körülmény például egészségtelenül felgyorsult élettempónk, amelynek egyik egyenes következménye lett a beszédtempó gyorsulása, valamint a beszéd minőségi romlása. A környezetünkben megnövekedett mértékü háttérzajban az elnagyolt, pongyola artikuláció és a hanyag mondatszerkesztés is megnehezíti a megértést (vö. Bóna, 2005; Gósy, 2000; Heltai, Gósy, 2005). Ismeretes, hogy az elmúlt évtizedek a magyar oktatási rendszerben is számos változást hoztak. Általános tapasztalat, hogy a minőségi paraméterek mennyiségcentrikus irányba tolódtak el. Megnövekedett az elsajátítandó ismeretek köre, ugyanakkor a tanulni és továbbtanulni kívánók létszáma is. A nagy létszámú tanulócsoportokban egyre inkább háttérbe szorul az aktív nyelvi közlés igénye, az oktatók a modern technikai eszközökkel (például power pointtal, fénymásolatokkal) igyekeznek a tanításra rendelkezésre álló időt optimálisan kihasználni. A diákoknak azonban így egyre kevesebb lehetőségük van arra, hogy folyamatos visszajelzéseket adjanak, kérdezhessenek, beszélgethessenek, s ily módon napvilágra kerüljenek a megértés, értelmezés folyamatát esetlegesen akadályozó tényezők. A probléma gyökerei összességében egészen a kisgyermekkorig visszanyúlnak, majd élesen telítődnek az iskolai és egyéb szociális színtereken megnyilvánuló kedvezőtlen körülményekkel.

Itt jegyezzük meg, hogy a jegyzetelés, mint tanulásmódszertani eszköz egyaránt részt vesz a tanulás input fázisában (információbevitelt szolgál, amikor például egy tanári előadás jegyzetelése történik meg), process fázisában (információfeldolgozást segít, amikor célja pl. a tananyag/szöveg átszerkesztése és/vagy memorizálása) és az output fázisában (abban az esetben, amikor egy vizsga során a tanuló által készített jegyzet is szerepet kap az értékelés során). Vagyis multifunkcionális jellegénél fogva a jegyzetelés jóformán a Mező-féle IPOOmodell szerint értelmezett tanulás valamennyi információfeldolgozó fázisában szerepet játszhat (Mező, 2011). Érdemes tehát alaposabban feltárni egy ilyen általános, többcélú tanulási módszer hátterét.

A következőkben áttekintjük, hogy egészséges esetben hogyan müködik az ember beszédfeldolgozó rendszere. Ebből kiindulva mutathatunk azután rá azoknak az összefüggéseknek egy részére, amelyek a beszéd feldolgozásának sikerességére épülő jegyzetelési tevékenységet befolyásolják. Az ilyen és ehhez hasonló kutatási eredmények támogathatják a tanulási nehézségek kialakulásának prevencióját, és hozzájárulhatnak az eredményes, sikeres jegyzetelési technikák elsajátításához (vö.: Mező, 2011), amelyek nemcsak az iskolai, hanem később a munkahelyi boldogulásunkat, előmenetelünket is nagymértékben meghatározzák.

\section{A beszédpercepció}

Az emberi agy igen összetett mechanizmusok mentén dolgozik, miközben a nyelvet valamilyen módon használja (legyen az beszédértés vagy beszédprodukció, illetőleg az olvasás- és az írástevékenységek változatainak bármely módja, pl. egy iskolai vagy munkahelyi jegyzetelő tevékenység). Kutatások tanúskodnak arról, hogy az említett folyamatok müködését a beszédfeldolgozási mechanizmusok ép vagy zavart volta jelentős mértékben befo- 
lyásolja (lásd például: Gerliczkiné Schéder, 2007; Gósy, 2007). Kívánatos tehát, hogy részletesen is megismerkedjünk a beszédfeldolgozó rendszer müködési sajátosságaival.

Abból kell kiindulnunk, hogy a teljes beszédfeldolgozási folyamat hátterében olyan bonyolult idegi müködések állnak, amelyek jelentős részéröl még nincs pontos tudományos ismeretünk (Bóna, 2007; Gósy, 2005). A kutatást megnehezíti, hogy rejtetten müködő mechanizmusokról van szó, melyek zavarai egyértelmüen nem hívják fel magukra a figyelmet (Gerliczkiné Schéder, 2007). Ettől függetlenül nem mondhatjuk, hogy a beszédmegértés passzív, hanem nagyon is aktív folyamat (Gósy, 2005). A teljes beszédmegértéshez szükséges működési rendszer kialakulása egy velünk született „vázra” épülő fejlődési, tanulási folyamat eredménye. A beszédészlelés és a beszédmegértés mechanizmusait ezért „részképességekként”, ,adott funkciórendszeren belüli részfolyamatokként" definiálhatjuk (Graichen, 1973, 122. o.), melyek müködési problémáit részképességzavarokként tárgyalja a gyógypedagógiai szakirodalom (Farkasné, 2006).

A beszéd feldolgozása magában foglalja a hallást, a beszédészlelést (a percepciót) és a beszédmegértést. Ezeknek a folyamatoknak a feltételezett müködésmódozatairól készült elméleteket különféle nyelvi modellek képviselik. Ezek a modellek a nemzetközi szakirodalomban változó megítélés alá esnek, közülük azonban a hierarchikus szintek összefüggésrendszerében való gondolkodás tünik a legelfogadottabbnak (Gósy, 2005).

Ebben a rendszerben a hierarchia legalsó szintjén a hallás folyamata foglal helyet. A hallás a hangingerek érzékelése, melynek eredményeképpen egyrészt a hangok fizikai sajátságai percipiálódnak, másrészt komplex hallási benyomások integrálódnak közvetlenül fülünk tőszomszédságában (Beke, 1996). Az eredményes beszédfeldolgozás alapja mindenekelőtt az ép hallás. A beszédfeldolgozási zavarok hátterében álló leggyakoribb szervi probléma a halláskárosodás. A halláskárosodások bizonyos típusai azonban kezelhetők (vagy kompenzálhatók). Ilyenek a gyermekkori hurutos megbetegedések okozta átmeneti, vezetéses típusú hallászavarok. Hosszas fennállásuk esetén és megfelelö kezelés hiányában azonban a hallásra épülö további beszédfeldolgozási szinteken zajló müködéssorozatok is tartósan károsodhatnak (Gósy, 2000), és ezek a problémák a legfrissebb orvosi kutatások szerint sokkal gyakrabban vezetnek tanulási nehézségekhez, mint azt korábban feltételeztük (Schneider, Simon, 2007).

A hallásalapú érzékelés közvetlen eredményeire beszédészlelési alap- és részfolyamatok épülnek, melyek a hangkapcsolatok, hangsorozatok felismerését eredményezik (Gósy, 2005). A beszédészlelés feldolgozási alapmechanizmusai velünk születettek, a beszéd percepciós készsége ösztönösen, automatikusan jelentkező, a nyelvi tapasztalattól teljesen független neurális rendszer produktuma (Csépe, 2005; Katona, 1996). A hallási elemzés eredményeire épülő beszédészlelés folyamatát is hierarchikus szerveződésben képzeljük el. Három alapszintjének - az akusztikai, fonetikai és fonológiai szinteknek - a müködését a velük bonyolult összefüggésrendszerben funkcionáló részfolyamatok egészítik ki: a szeriális észlelés, a beszédhang-differenciálás, a transzformációs észlelés, a ritmusészlelés és a vizuális észlelés (Gósy, 2005).

Az akusztikai elemzés az elhangzott hangok, hangsorozatok akusztikai tulajdonságainak (időtartamának, frekvenciaszerkezetének, intenzitásának) felismerése. A fonetikai elemzés beszédhang-beazonosítást, míg a fonológiai elemzés beszédhang-fonéma megfeleltetést jelent. E három beszédészlelési alapszint nem megfelelő müködése nehézséget eredményez többek között az idegen nyelvek tanulásakor, a grammatikai struktúrák felismerésében, valamint az írott nyelv elsajátításában és használatában (Gósy, 2005; Lengyel, 1999). A nyelvi hallási információk akusztikus elemzését a hallókéreg, fonológiai feldolgozásukat a hallókéreg mögött és alatt elhelyezkedő, bal oldali temporalis sulcus, valamint a temporális lebeny középső tekervénye végzi. PET-vizsgálatok tanúságai alapján a fonetikai feldolgozáshoz bal féltekei, míg a hangsúlyviszonyok felismeréséhez jobb féltekei relatív túlsúlyú aktiváció kapcsolódik. Igazolódott továbbá, hogy a bal félteke a finomabb idői feldolgozásra 
specializálódott, míg a jobb féltekében a hangmagasságok jobb megkülönböztetését szolgáló spektrális felbontás a jobb (Zatorre és tsai., 1992, idézi Lukács, Pléh, 2003).

A szeriális észlelés sorozatészlelést jelent. Beszédészlelési feldolgozó rendszerünknek ez a részfolyamata biztosítja azt, hogy az elhangzott hangsorozatokat képesek legyünk az elhangzásuknak megfelelő egymásutániságban azonosítani. A szeriális észlelés hibái a beszédalapú írástevékenységekben többféleképpen is tetten érhetők: jellegzetes hibatípus a leírtakban a beszédhang- (illetve betü-) hiány, egyes szótagok hiánya, felesleges hangok (illetve betük) betoldása a szavakba, bizonyos beszédhangok (illetve betűk) felcserélése, vagy a teljes hangsor (illetve betüsor) egyéb, megmagyarázhatatlan jellegü eltorzítása. A beszédhangdifferenciálás zavara a beszédhangok egymástól való megkülönböztetési nehézsége. Ilyenek a magán- és mássalhangzók időtartambeli megkülönböztetésének problémái, a zöngésségzöngétlenség tekintetében való döntés vagy a mássalhangzók képzési helyének bizonytalansága. A transzformációs észlelés biztosítja az egyes beszédhangok valamely vizuális jelenségre (adott esetben grafémára) történő átvitelét, ami az olvasás- és írástevékenység alapja. A beszédritmus észlelése az elhangzott szótagok időtartamának, a szótagok és szavak határainak felismerése. Zavara nemcsak, hogy jellegzetes helyesírási hibákat indukál, hanem a teljes beszédmegértési folyamat sikerességét is alapvetően befolyásolja, hiszen: „Újra és újra megerősítést nyer, hogy a szótagok központi szerepet töltenek be a folyamatos beszéd elemzéséhez (parsing) nélkülözhetetlen észlelési egységekre (perceptual unit) történő bontásban" (Csépe, 2007, 22. o.). A vizuális észlelés az artikulációs gesztusok és egyéb, nonverbális és metakommunikációs jelzések percepciója. Adott esetben a beszédmegértés kiegészítő eleme.

A beszédpercepcióban bekövetkezett hibákat a mindennapi szóhasználatban félrehallásoknak nevezzük, tudományos megnevezésük téves észlelés (Bóna, 2004). Saját vizsgálataink azt mutatják, hogy a téves észlelések a beszédmegértést és az értelmezést is negatív irányban befolyásolják, ami az iskolai előadásokon készített hallgatói jegyzetekben megmutatkozik (Gerliczkiné Schéder, 2008).

\section{A beszédmegértés}

A beszédfeldolgozás hierarchiájában a beszédészlelés alap- és részfolyamatainak eredményeire épülö beszédmegértés jelenti a jelentésazonosítást, a szemantikai (jelentéstani) és szintaktikai (mondattani) feldolgozást (Gósy, 2005). Elméletileg beszélhetünk szóértésről, mondatértésről és szövegértésről, összefüggő beszéd befogadása esetén azonban nem célszerü ezeket a folyamatokat elkülönítve kezelni, hiszen az elemzés feltehetöleg nem szigorú értelemben egymás után zajlik az egyes nyelvi szinteken, hanem egy időben, több szinten, egyszerre is történhet.

A szókincsünket (valamint a nyelvtani elemeket, szabályokat) tároló ún. mentális lexikonunk aktív és passzív része határait tekintve rugalmasan változó. Nagyságának behatárolását megnehezíti a szófogalom tisztázatlansága (például az egyes szám harmadik személyü személyes névmásunk - ő - egyetlen szó, de adott esetben egy egész mondat is lehet, stb.). Aktív szókincsnek nevezzük mindenesetre az általunk ismert szavak közül azokat, amelyeket gyakran használunk, így minden nehézség nélkül meg is értünk, míg az ember passzív szókincsébe olyan kifejezések tartoznak, amelyeket ismer ugyan, de ritkán használ, következésképp jelentésük azonosítása is bizonytalanabb a számára. Kutatások bizonyítják, hogy a beszédfeldolgozás folyamatában a szavakhoz való lexikális hozzáférést befolyásolja többek között azok akusztikai szerkezete, fonotaktikai szerveződése, gyakorisága, az elhangzott beszéd tempója stb. (lásd: Gósy, 1991; Gósy, 1997; Gósy, 2005). Érdekes kérdést vet fel eközben, hogy az egyes szóalakok holisztikusan (egészlegesen), avagy analitikusan 
tárolódnának, illetve volnának hozzáférhetők mentális lexikonunkban (pl. külön a szótövek és külön a toldalékmorfémák - Pléh, 2000). Magyar kutatások azt igazolták, hogy a magyar anyanyelvü ember mentális szótárában külön tárolódnak a szótövek és az igekötők, az elhangzó beszéd feldolgozása pedig morfológiai dekompozícióval történik (vesd össze: Juhász és Pléh, 2001). Képalkotó eljárásokkal igazolható, hogy a lexikális reprezentáció kizárólag bal agyféltekés elhelyezkedésü, és az egyes lexikai elemek szemantikai kategóriánként elkülönült tárolást mutatnak: pl. az állatok az alsó halántéki lebenyben, az eszközök a nyakszirti-halántéki-fali lebenyek érintkező szögletében reprezentálódnak (Hámori, 1999).

„A mondatértés az a folyamat, ahogyan a szavakat szószerkezetekké kapcsoljuk össze, a szerkezetekhez mondattani funkciót rendelünk, illetőleg ezeket a szerkezeteket szemantikailag is értelmezzük" (Gósy, 2005, 176. o.). Ebben a folyamatban a grammatikai és a szemantikai elemzések egymást segítik, erősítik. Az agglutináló (azaz tipikusan toldalékoló) nyelvek (mint a magyar is) döntéseiket nagy biztonsággal alapozzák az alaktani szabályokra (Pléh, 2000), egy mondat feldolgozásakor minden bizonnyal a toldalékoknak jut elsődleges figyelem, ezt követi a szórend, majd az egyeztetés. Agyi direkt elektromos ingerléses technikával megfigyelhető, hogy a mondat különböző nyelvtani elemeit (például névelők, névutók, jelzők, főnevek) a beszédkéreg egymástól eltérő kisebb mezői értékelik, azaz „az agy a leírt szöveg látásával, illetve a beszéd hallásával szinte egy időben atomizált elemeire bontja a mondatot (s ez a kéregben térben is mozaikosodik)" - Hámori (1999, 30. o.). Érdekes, hogy az adott mondat, beszédrészlet a beszédkéregben többszörösen is képviselve van, mindenütt egyedi elemeire szétbontva. Funkcionális mágneses rezonanciás leképezési technikával kimutatták, hogy a Wernicke-areán kívül (amely a beszédmegértés vezető kérgi területe) bal féltekés halántéki-fali régiók (a fusiform és angulanis tekervények), illetve homloklebenyi (a motoros - Broca - kéreg előtti) területek is részt vesznek a beszédmegértési folyamatokban. Splitbrain-vizsgálatokból az is kiderült, hogy a jobb félteke csak tárgyakat, föneveket képes azonosítani, igéket nem. A nyelvi és beszédközpontok az esetek többségében (kezességtől függetlenül) a bal féltekéhez tartoznak (Hámori, 1999).

A mondaton belüli szerkezeti és logikai összefüggések megértésének problémája a mondatértés zavara. A szövegértés zavaráról akkor beszélünk, ha a mondatok közötti összefüggések, az egybetartozó gondolati egységek feldolgozása sérül, a részletek felismerése sikertelen. A szövegértés során valószínűleg „többszörös kulcsokat” használ a befogadó, melyek részben univerzálisak, részben nyelvspecifikus sajátosságok (Gósy, 2005).

Az összefüggő beszéd megértését az eddig felsoroltakon kívül nagymértékben befolyásolják még az alábbi tényezők:

- A hallgató már meglévő ismeretei: a befogadó személy gyakran mintegy elébe megy a kapott anyagnak, tehát a megértést valamilyen elvárás is megelözi (Pléh, 1984; Tolcsvai Nagy, 2001).

- Előfordul, hogy a hallgató általános müveltsége korrekciós lehetőségként sokszor értelmet ad a valójában meg nem értett közlésegységeknek.

- Befolyásoló tényező a szavak nyelvhasználati gyakorisága is: a gyakoribb szavakat a valóságos szóinger jelenléte nélkül is hajlamosabbak vagyunk „felismerni” (Pléh, 1984).

- Nyilvánvaló, hogy a szövegösszefüggés, a kontextusra való támaszkodás lehetősége eleve nagymértékben segíti a beszédmegértés folyamatát. Ezen belül a jelentés és a nyelvtani szerkezet egyaránt befolyásoló tényező. Kísérleti eredményeink alapján az igazolódott, hogy a megértés során jobban támaszkodunk a nyelvtani szerkesztésmódra, mint a tartalomra, továbbá egyértelmü, hogy a közbeékelt szerkezet(ek)et tartalmazó, ill. többszörösen beágyazott mondatok mindig nehezebben érthetők (vö. Gerliczkiné Schéder, 2008; Pléh, 1974; Pléh, 1984). 
$\mathrm{Az}$ észlelt nyelvi üzenet megértésének folyamatában valószínüleg először egy fiktív, számtalan szemantikai-szintaktikai struktúra lehetőségét rejtő fogalmi tartomány aktivizálódik a hallgató tudatában. Az általunk használt szavak lexikai jelentése ugyanis bonyolult asszociációs viszonyok csomópontja. A nyelvi elemek kombinációja során azonban ezeknek csak bizonyos szeletei aktiválódnak, így a hallgató a lehetséges nyelvi aktusok közül a kontextusnak leginkább megfelelőt választja ki. Vagyis ebben az értelemben a megértési folyamat nem más, mint választás (Szécsi, 2003).

Az asszociációk szintjén a hallgató a megértett közlésegységeket értelmezi, összekapcsolja a hosszú távú memóriájában már korábban tárolt ismeretekkel. A szöveginterpretáció, ill. szöveghatás nem más, mint az elhangzott szövegbe kódolt üzenet jelentésének újrateremtése. A szöveg grammatikai-szemantikai-stiláris sajátságain túl a szituáció jellemzőiből, a paralingvisztikai jellegzetességekből és egyfajta általános világtudásból képesek vagyunk megítélni, hogy egy megnyilatkozás milyen illokucionális beszédtett (Szikszainé Nagy, 2004).

\section{A memóriarendszerek szerepe}

A különféle beszédek (például iskolai előadások, üzleti megbeszélések, tárgyalások stb.) lejegyzése (történjen az akár kivonatos, kézi vagy gépi, akár szó szerinti, gyorsírásos formában) a beszédészlelési, -megértési és értelmezési mechanizmusok gördülékeny és pontos müködésével összhangban egyéb kognitív funkciókat is igénybe vesz. Ez a fejezet ezek közül a memóriarendszereink szerepével foglalkozik.

Az összefüggő beszéd megértése többnyire egy-egy globális egység feldolgozásán keresztül valósul meg. Ez azzal jár együtt, hogy rövid ideig gyakran több mondatból álló gondolategységeket is memorizálnunk kell ahhoz, hogy a lényegkiemelés (vagy gyorsírásos nyomonkövetés esetén a beszélö tempójával való együtthaladás) megtörténhessen. Kivonatos jegyzetelés esetén a lényegkiemelés javarészt szubjektív döntés eredménye, amelyet a pszichológusok szerint külső és belső tényezők befolyásolnak: a külső tényezők az inger fizikai jellemzőivel, a belső tényezők az egyén motivációjával és elvárásaival kapcsolatosak (Hofmeister-Tóth és Mitev, 2007; Mező, 2011). A szükséges tartalmi és nyelvi elemek kiválasztásának, illetőleg a megfelelő szabályok hozzárendelésének eredményeként épül fel végül az írás. A jegyzetelés során ezért a rövid és a hosszú távú memória müködésmódozatainak kihasználása egyaránt meghatározó szerepet tölt be.

Az 1950-es évek óta figyeltek fel arra, hogy a nagyagy jobb és bal oldali középső-oldalsó területének, a mediális temporális lebenynek - hippocampusnak - a sérülése az emlékezeti funkciók súlyos károsodásához vezet (lásd: epilápsziásokon végzett mütétek, amnesztikus szindrómák stb.). A hippocampus-struktúra napjainkra az idegrendszer egyik legtöbbet tanulmányozott területe lett. A kísérletek azt mutatják, hogy ez az agyterület nemcsak az emlékezeti, hanem a tanulási folyamatban is fontos szerepet tölt be (vö: Káli és Acsády, 2003). Bebizonyosodott továbbá, hogy különbséget kell tennünk nyelvi (verbális) és nem nyelvi (téri-vizuális) emlékezési folyamatok között. Megfigyelték ugyanis, hogy a hippocampus-formáció mütéti sérülése nyomán kialakult emlékezeti zavarok jobbára csak nyelvi szinten jelentkeznek, míg a nem nyelvi funkciók sokkal kisebb valószínüséggel szenvednek károsodást (vö: Bednorz, Schuster, 2006; Halász, 2003).

Egy előadás jegyzetelése lehetetlen feladat volna a hippocampus müködésének hiányában. Ilyenkor ugyanis elengedhetetlen, hogy az anyag reprezentációjának építésekor folyamatosan fenntartsuk emlékezetünkben a mondat első felét vagy a szöveg korábbi részeit. Mindezt rövid távú memóriánk müködése biztosítja. A rövid távú memória kapacitása korlátozott, a felnőtt emberek többségénél $7 \pm 2$ tétel (Atkinson és tsai., 1995). Maddeley mutatott rá először arra, hogy rövid távú emlékezetünk többkomponensü, aktív és dinamikus rendszer: nemcsak az információk tárolására, hanem bizonyos müveletek végzésére is hivatott (Németh, 2002). 
Napjaink egyik legismertebb koncepciója szerint a rövid távú emlékezet munkamemóriaként (working memory) definiálható, amely fenntartja és manipulálja az információt, és amely három komponensből áll: két modalitásspecifikus alrendszerből, amelyek a verbális, illetve a téri-vizuális információ fenntartásában és manipulációjában vesznek részt, valamint egy úgynevezett központi végrehajtó rendszerből, amely összeköttetést teremt a két alrendszer, illetve a hosszú távú emlékezet között, és felelős a kognitív erőforrások elosztásáért (Racsmány, 2001). A beszédalapú információk elsődleges tárolásáért a munkamemória egyik alrendszere, az ún. fonológiai hurok a felelős, amely a hallott anyag rövid idejü verbális ismételgetését biztosítja. A nagyobb munkamemória-kapacitás - mely akár mnemotechnikákkal, emlékezést segítö technikákkal (vö.: Mezö, 2011) bizonyos keretek között növelhetö pedig kétségtelenül jobb beszédmegértést és sikeresebb szövegintegrációt eredményez.

Az előadó által közvetített információknak az a része, amely a jegyzetelő figyelmét megragadja, eszerint a rövid távú emlékezetbe kerül. Az anyag megtartása és manipulálása a munkamemória müködésének függvénye. Az előadásból kiemelt, értelmezett közlésegységek papírra vetése majd újabb komplex, reproduktív folyamat lesz. Ennek érdekében a kapott tudattartalomhoz nyelvi elemeket és szabályokat válogatunk mentális lexikonunkból, ezeket megfelelö sorrendbe rendezzük, végül az egészet írástevékenységbe transzformáljuk.

\section{Összegzés}

Elméletben sok ismeretünk van már a beszédfeldolgozó apparátus müködésének lokális szerveződéséröl. Nehezebb azonban nyomon követni azt az idegrendszeri folyamatot, amelynek során a térben mozaikosodott nyelv értelmes és (újra)értelmezett információs egységgé áll össze az ember tudatában. Az úgynevezett funkcionális nyelvi és beszédzavarokat még nehezen tudjuk ,utolérni”. A beszélt nyelvi előadások szimultán írásbeli jegyzetelése is nagyon összetett funkcionális háttérmechanizmusokra támaszkodva zajlik. Az előadásjegyzetekben azonosított hibákból vissza lehet következtetni bizonyos beszédfeldolgozási zavarokra. Azt azonban, hogy e folyamatok mögött milyen idegi mechanizmusok állnak, csak olyan müszeres eljárásokkal lehetne vizsgálni, melyek müködés közben teszik egyszerre láthatóvá és időben nyomon követhetővé az agyi mechanizmusokat (éber tudatállapotban, tevékeny, mozgásos feladattal összehangolt kísérleti helyzetben). Ezek még nem megoldott lehetöségek.

A nehezített vagy zavart beszédfeldolgozás végigkísérheti az egyént egy életen át, jelentős hátrányt okozva a mindennapokban, a tanulásban és a munkavégzésben. Talán meglepő, de az ép hallás nem feltétlenül függ össze ép beszédészleléssel és beszédmegértéssel! Tapasztalataink szerint a felsőoktatásban tanuló fiatalokkal szemben támasztott követelmények gyakran hozzák felszínre a beszédfeldolgozási nehézségeket. A legszembetűnőbb az évfolyam-előadások megértésének, értelmezésének és jegyzetelésének problémája. Mindez különös figyelmet érdemel, hiszen tanulmányaink során az új ismeretek jelentős részét hallás révén, a beszélt nyelv feldolgozásával szerezzük.

Tudományosan kevesen foglalkoznak a 14-18 éves, vagy idősebb fiatalok beszédpercepciós vizsgálatával. Saját - a Különleges Bánásmód címü lap további számában közlésre kerülő kutatásaink talán új megvilágításba helyezik az egyre szaporodó tanulási problémák oki hátterét.

\section{Irodalom}

Atkinson, R. L. , Atkinson, R. C., Smith, E. E. és Bem, D. J. (1995). Pszichológia. Budapest: Osiris.

Bednorz, P., Schuster, M. (2006). Bevezetés a tanulás lélektanába. Budapest: Medicina 
Könyvkiadó Rt.

Beke, A. (1996). A beszédpercepció fejlődésének neurológiai háttere. In Gósy (szerk.), pp. 351.

Bóna, J. (2004). A beszédészlelési folyamat megakadásai. Beszédkutatás 2004. (pp. 223-230).

Bóna, J. (2005). A hadaró és a gyors beszéd temporális sajátosságai. Magyar Nyelvőr 129/2. (pp. 235-242)

Bóna, J. (2007). A felgyorsult beszéd produkciós és percepciós sajátosságai. PhDdisszertáció. Budapest: ELTE.

Büky, B., Egyed, A., Pléh, Cs. (szerk.) (1984). Nyelvi képességek-fogalomkincs - megértés. Budapest: Tankönyvkiadó.

Csépe, V. (2005). A nyelv agyi reprezentációjának fejlődési változásai és zavarai. Magyar Tudomány 2005/11. (pp. 1336-1346)

Csépe, V. (2007). A beszédészlelés kritikus kérdései és a beszédészlelés fejlődése „neuro”nézetböl. In Gósy Mária (szerk.), pp. 20-43.

Farkasné Kristóf, Zs. (2006). Lehetőségek a tanulási problémák korai felismerésében és megelőzésében. Új Pedagógiai Szemle 2006/6. (pp. 98-106)

Gerliczkiné Schéder, V. (2006). A gyorsírás és a nyelv kapcsolata. Szemiotikai Tájékoztató 2006/1. (pp. 7-12)

Gerliczkiné Schéder, V., Tukacsné Károlyi, M. (2007). Lexical Access in the Work of the Stenographer of Speeches. In Kiss, G. (szerk.) (2007). Segédkönyvek a nyelvészet tanulmányozásához 92. pp. 41-47.

Gerliczkiné Schéder, V. (2007). Felnőttkori beszédfeldolgozási nehézségek. In Gósy (szerk.), pp. 301-310.

Gerliczkiné Schéder, V. (2008). A beszédmegértési és jegyzetelési nehézségek összefüggései fiatal felnötteknél. PhD-disszertáció. Budapest: ELTE.

Gósy, M. (1991). Szavak és mondatok megértésének kérdéseiről. Magyar Nyelv 87. (pp. 151162)

Gósy, M. (szerk.) (1996). Gyermekkori beszédészlelési és beszédmegértési zavarok. Budapest: Nikol Kkt.

Gósy, M. (1997). A magyar beszéd tempója és a beszédmegértés. Magyar Nyelvőr 121. (pp. 129-139)

Gósy, M. (2000). A hallástól a tanulásig. Budapest, Nikol Kkt.

Gósy, M. (2000). Állandóság és változás a beszédben. Magyar Nyelv 96/1. (pp. 1-13)

Gósy, M. (2004). Fonetika, a beszéd tudománya. Budapest: Osiris.

Gósy, M. (2005). Pszicholingvisztika. Budapest: Osris.

Gósy, M. (szerk.) (2007). Beszédészlelési és beszédmegértési zavarok az anyanyelvelsajátításban. Budapest: Nikol Kkt.

Graichen, J. (1973). Teilleistungsschwächen, dargestellt an Beispielen aus dem Bereich der Sprachbenutzung. Kinder- und Jugendpsychiatrie, Psychosomatik und Psychotherapie 1. (pp. 113-143)

Halász, P. et al. (2003). Kognitív zavarok epilepsziában - az epilepszia mint a kognitív kutatás eszköze. In Pléh et al. (szerk.), pp. 688-697.

Hámori, J. (1999). Az emberi agy aszimmetriái. Budapest-Pécs: Dialóg-Campus Kiadó.

Heltai, P., Gósy, M. (2005). A terpeszkedő szerkezetek hatása a beszédfeldolgozásra. Magyar Nyelvör 129. (pp. 473-487)

Hofmeister-Tóth, Á., Mitev, A. Z. (2007). Üzleti kommunikáció és tárgyalástechnika. Budapest: Akadémiai Kiadó.

Juhász, L., Pléh, Cs. (2001). Többmorfémás szavak megértése a magyarban In Pléh, Lukács (szerk.), pp. 11-38.

Imre, A. (2007). Az anyanyelv-elsajátítás vizsgálata. In Gósy Mária (szerk.), pp. 58-69. 
Káli, Sz., Acsády, L. (2003). A hippocampusfüggő memória neurobiológiai alapjai. In Pléh et al. (szerk.), pp. 360-384.

Kiefer, F. (szerk.) (2000). Strukturális magyar nyelvtan 3. Budapest: Akadémiai Kiadó.

Katona, G. (1996). A hallás fejlődése és vizsgálati módszerei. In Gósy (szerk.), pp. 8-29.

Kontra, Gy. (1962). Az emberi test. Budapest: Gondolat.

Lengyel, Zs. (1999). Az írás. Kezdet-folyamat-végpont. Az írástanulás pszicholingvisztikai alapjai. Budapest: Corvina.

Lukács, Á., Pléh, Cs. (2003). A nyelv idegrendszeri reprezentációja. In Pléh et el. (szerk.), pp.528-560.

Mező F. (2011): Tanulás: diagnosztika és fejlesztés az IPOO-modell alapján. K+F Stúdió Kft., Debrecen.

Németh, D. (2002). Munkamemória, fejlődés, nyelv. In Racsmány, Kéri (szerk.), pp. 83-100.

Pléh, Cs. (1974). Mondat és emlékezet I-II. Magyar Pszichológiai Szemle 31. (pp. 24-35, 147158)

Pléh, Cs. (1984). A megértés és a szövegalkotás pszichológiája. In Büky et al. (szerk.), pp. 271-373.

Pléh, Cs. (2000). A magyar morfológia pszicholingvisztikai aspektusai. In Kiefer (szerk.), pp. 951-1020.

Pléh, Cs., Lukács, Á. (szerk.). (2001). A magyar morfológia pszicholingvisztikája. Budapest: Osiris.

Pléh, Cs., Kovács, Gy., Gulyás, B. (szerk.). (2003). Kognitív idegtudomány. Budapest: Osiris.

Racsmány, M., Kéri, Sz. (szerk.) (2002). Architektúra és patológia a megismerésben. Budapest: BIP.

Schneider, J., Simon, F. (2007). A beszédhallás diagnosztikája. In Gósy (szerk.), pp. 104-112.

Szécsi, G. (2003). A kommunikatív elme. Budapest: Áron Kiadó.

Szikszainé Nagy, I. (2004). Leíró magyar szövegtan. Budapest: Osiris.

Tolcsvai Nagy, G. (2001). A magyar nyelv szövegtana. Budapest: Nemzeti Tankönyvkiadó.

\section{Internetes hivatkozások}

Net1: Racsmány M. (2001). A munkamemória müködése és patológiája. Letöltés: 2016. 02. 26. Web: http://epa.oszk.hu/00700/00775/00035/index.htm 